\title{
Thyroid Gland Follicular Dendritic Cell
} Sarcoma

National Cancer Institute

\section{Source}

National Cancer Institute. Thyroid Gland Follicular Dendritic Cell Sarcoma. NCI Thesaurus. Code C156408.

A rare follicular dendritic cell sarcoma involving the thyroid gland. It may be associated with chronic lymphocytic thyroiditis. 